\title{
Exploring Geographical Factors for the Formation of Sector Boundaries of the Liberation War of Bangladesh 1971
}

\author{
Bibi Hafsa \\ Assistant Professor, Department of Geography and Environment, Jahangirnagar University, Savar, Bangladesh \\ Email: hafsa@geography-juniv.edu.bd
}

How to cite this paper: Hafsa, B. (2020). Exploring Geographical Factors for the Formation of Sector Boundaries of the Liberation War of Bangladesh 1971. Advances in Historical Studies, 9, 190-210. https://doi.org/10.4236/ahs.2020.94017

Received: September 10, 2020

Accepted: November 27, 2020

Published: November 30, 2020

Copyright $\odot 2020$ by author(s) and Scientific Research Publishing Inc. This work is licensed under the Creative Commons Attribution International License (CC BY 4.0).

http://creativecommons.org/licenses/by/4.0/

\section{(c) (i) Open Access}

\begin{abstract}
The Liberation War of 1971 is a chapter of great pride in the history of Bangladesh. The nine-month long bloodiest War of Liberation war by the peoples of Bangladesh in 1971 will forever remain recorded as one of the most glorious chapters in human history. It is just not possible to write down the whole history of this glorious war, simply one or two research because there are innumerable known and unknown stories and events regarding it. However, this study is paramount of portraying the bloody historical part of the Geographical Factors influencing forming the Sector Boundaries of the Liberation War of Bangladesh 1971. In the War of Liberation, the whole geographical area of East Pakistan (present Bangladesh) was strategically divided into eleven sectors with a sector commander for each of them. The formation of the sectors played a key role in demolishing the Pakistani army. That was the very efficient and crucial strategy for winning the Liberation War. The formation of the sector boundary is not political, it is more Geographical. It is formed based on innumerable geographical features. This research paper earnestly studies very crucial points regarding the influences and roles of geographical settings in determining planning as well as strategically aspects of the Liberation War of Bangladesh. The liberation war of Bangladesh is the nation's important issue and thus required this type of inquisitive research which will see the history in different perspectives. It will be helpful for the current generation to understand the geographical aspect of a nation's birth. It is a historical research and this study explored based on descriptive literature review. The study has collected data based on literature survey and data presented by table, figure, diagram and map with the help of GIS techniques.
\end{abstract}

\section{Keywords}

Liberation War, Sector, Boundary, Geographical Factor 


\section{Background}

The Liberation war has been a historic issue for the peoples of Bangladesh. The nine-month long War of Liberation war by the peoples of Bangladesh in Provisional Government of Bangladesh (1971) will forever remain recorded as one of the most glorious chapters in human history (Mukul, 2004). The sovereign and independent People's Republic of Bangladesh, as it stands today, is the outcome of an arduous struggle of the peoples of Bangladesh. The Liberation War did not come overnight. It had been continuing for nine months. The war continued March to December in 1971. The Liberation War of 1971 is a chapter of great pride in the history of Bangladesh (Government of Bangladesh, 2006). This formerly East Pakistan is now known as Bangladesh. Bangladesh is geographically located between $20^{\circ} 34^{\prime}$ to $26^{\circ} 38^{\prime}$ North Latitude and $88^{\circ} 01^{\prime}$ to $92^{\circ} 41^{\prime}$ East Longitude.

The first Bangladesh Sector Commanders Conference was held in the week of July 11-17, 1971 at 8 no. Theatre Road, Kolkata of West Bengal (Mamun, 2012). Main focus of this conference was planning the strategy of the Liberation war. In this conference, many strategies were documented for planning for the Liberation War. First strategy was to detect the sector boundaries of Bangladesh. In the War of Liberation in 1971, the whole geographical area of East Pakistan was strategically divided into eleven sectors with a sector commander for each of them. After this conference, the Bengali Force was organized and formed for the independence struggle. It was significant in the light of its official creation and formation as Bangladesh Forces, its command structuring, sector reorganization, reinforcement and appointing war commanders was its principal focus of this conference (Rahman, 1982).

The conference was presided over by the Prime Minister of Bangladesh, Tajuddin Ahmed, and General M. A. G. Osmani, during which General Muhammad Ataul Gani Osmani received his promotion from Colonel and was, reinstated from retirement to active duty into the Armed Forces of Bangladesh as its senior most official. General M. A. G. Osmani had thereby been appointed Commander in Chief of all Bangladesh Forces and Group Captain Abdul Karim Khandker, appointed as Deputy Chief of Command of all Bangladesh Forces. Principal participants of this conference were Squadron Leader M. Hamidullah Khan, Major Ziaur Rahman, Wing Commander M Khademul Bashar, Major M. A. Jalil, Captain Haider, Lt. Col. Abdur Rab (Maniruzzaman, 1980; Rahman, 1982). In this meeting, Bangladesh was divided into Eleven Sectors under Sector Commanders. Sector Commanders directed the guerrilla warfare. For better efficiency in military operations, each of the sectors was divided into a number of sub-sectors (Banglapedia, 2012).

The Liberation war was planned sector wise where the whole country was divided into 11 sectors. That was the very efficient and crucial strategy for winning the War. Whole country sub-divided into eleven parts which helped the freedom fighters to battle according to Sector commander's guidelines. These sectors were very important behind the success of battles during the Liberation war of 
Bangladesh. The formation of the sector boundary is not political, it is more Geographical. It is formed based on diverse geographical features. This research paper earnestly studies very crucial points regarding the influences and roles of geographical settings in determining planning as well as strategically aspects of the Liberation War of Bangladesh. The liberation war of Bangladesh is the nation's important issue and thus required this type of inquisitive research which will see the history in different lenses. It will be helpful for the current generation to understand the geographical aspect of a nation's birth.

It is just not possible to write down the whole history of this glorious war, simply because there are numerous known and unknown stories and events regarding it. However, this study is important in portraying the sanguinary historical part of the Geographical Factors influencing forming the Sector Boundaries of the Liberation War of Bangladesh 1971. This study was conducted based on a secondary descriptive literature survey. This study has collected data based on literature survey and data presented by Table 1, diagram (Figure 1), and map with Arc map. The scope of this study is presented in diagram below.

\section{Aim and Objectives}

The broad aim of this research work is to reconnoiter the geographical factors contributing to form the divergent sectors of the Liberation war of Bangladesh 1971. To fulfill this study, researcher grasp a few objectives. These are:

1) To enumerate the sectors during the Liberation War of Bangladesh 1971;

2) To examine the geographical settings of each of the sectors of the liberation War of Bangladesh;

3) To construct the sector map of the liberation war of Bangladesh 1971.

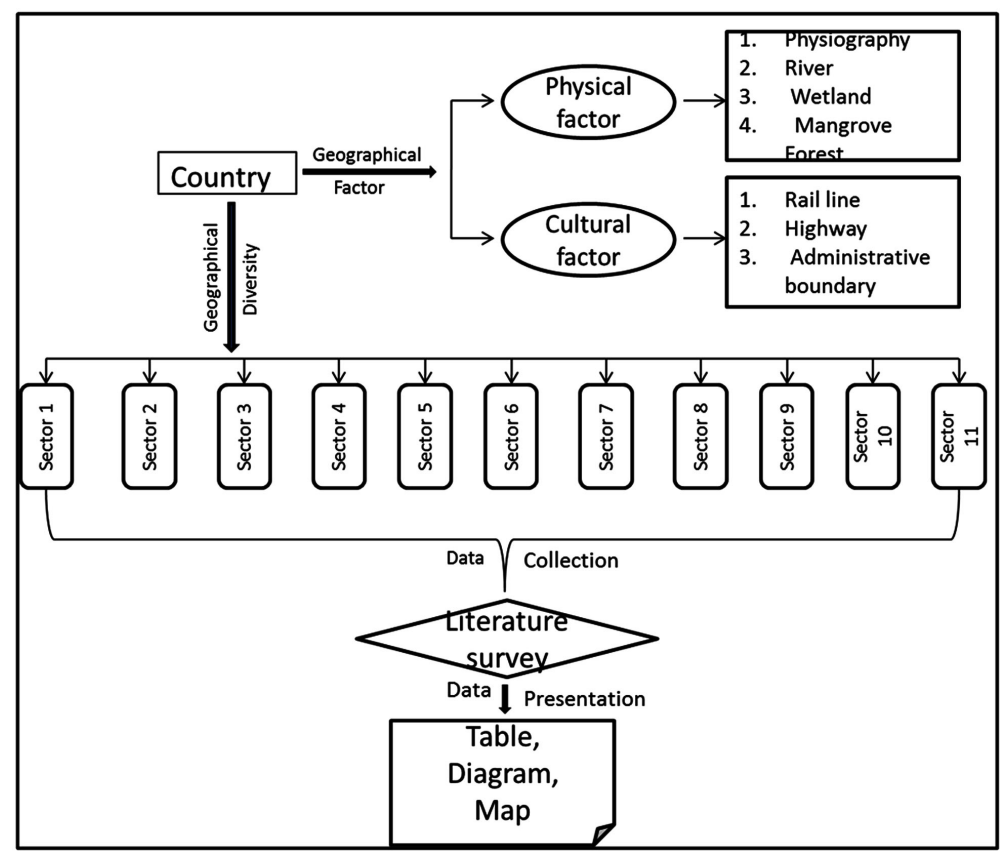

Figure 1. Scope of the study. 
Table 1. Methodology.

\begin{tabular}{|c|c|c|c|}
\hline Objectives & Required data & Techniques/Tools & Expected output \\
\hline $\begin{array}{l}\text { To enumerate of the } \\
\text { sectors during the } \\
\text { Liberation War of } \\
\text { Bangladesh } 1971\end{array}$ & $\begin{array}{l}\text { Information of sectors } \\
\text { during the liberation } \\
\text { war }\end{array}$ & Literature Review & $\begin{array}{l}\text { Investigate the sectors } \\
\text { during the Liberation } \\
\text { War of Bangladesh }\end{array}$ \\
\hline $\begin{array}{l}\text { To examine the } \\
\text { geographical settings } \\
\text { of each of the sectors } \\
\text { of the Liberation War } \\
\text { of Bangladesh }\end{array}$ & $\begin{array}{l}\text { Geographical features } \\
\text { of Bangladesh }\end{array}$ & Literature Review & $\begin{array}{l}\text { Investigate } \\
\text { geographical settings } \\
\text { of Bangladesh }\end{array}$ \\
\hline $\begin{array}{l}\text { To construct the } \\
\text { sector map of the } \\
\text { Liberation War of } \\
\text { Bangladesh } 1971\end{array}$ & Objectives 1 and 2 & $\begin{array}{l}\text { Geo-referencing, } \\
\text { Geo-processing, } \\
\text { Projection conversion } \\
\text { Data standardization } \\
\text { Geo-processing } \\
\text { Arc View 3.3, Arc } \\
\text { Map 10.1.1 }\end{array}$ & $\begin{array}{l}\text { Mapping the sector } \\
\text { boundary of } \\
\text { Bangladesh }\end{array}$ \\
\hline
\end{tabular}

\section{Methodology}

This study is an archival type of study, each historical study depends on mainly secondary sources of data. This study also depends on Secondary sources of data, especially published deliberate data. Deliberate data means archival data which is preserved by the government. Literature review is an important factor of this research. "A literature review is a body of text and its main goal is to bring the reader up to date with current literature on a topic and forms the basis for another goal, such as the justification for future research in the area. It seeks to describe, summarize, evaluate, clarify and integrate the content of previous researches". So far only very few national level works have been done where information and facts related to the liberation war of Bangladesh are documented in detail. These are-Manuscript of the liberation war of Bangladesh (Bangladesher ShadinathaJuddo: Daliilpatro) by the ministry of information, Sector wise history of the liberation war (Bangladesher ShadinathaJuddo: SectorbhittikEtihas) by the ministry of liberation war affairs, Liberation War Encyclopedia (Muktijuddo Kosh) by renowned Professor Muntasir Mamun, and Upazila level field work from the Banglapedia research team. Unfortunately, none of this information is geo-referenced or spatially tagged. This lack is seriously causing identifying the boundary of the war sectors at present time. On the other hand, none of these works analyzed the cause-effect of the facts and events that took place during the liberation war of Bangladesh.

To achieve the objectives of the research work, three broad categories of research methods were considered. In the first phase, the collection of information from different published sources was crucial to mine the depth of the research work. As the collected data were both qualitative and quantitative as well as being historical evidence, are always subject to dispute, the researcher has gone through an in-depth verification process. The verification process was mainly 
relying on the presence of the information in multiple sources (mostly from sources published from the government organizations or renounced research organization).

The second phase of the research method mainly includes the selection of geospatial tools and techniques to digitalize the collected datasets. The major thrust was to prepare a spatial database for identifying war sectors. For this purpose different GIS and Remote sensing techniques were in operation to produce a geo-database. The third and final phase of research methodology of this research work includes the analysis and interpretation of the database over the geographical space of the country. However, an outline of the adopted tools and techniques to achieve the research objectives is briefly presented below.

\subsection{Data Collection Techniques}

\subsubsection{Literature Review}

One of the key influences on war strategy, today as well as yesterday, is geography. In the past, in fact, geography often was more important than strategy-actually determining the outcome of a battle or war. Diehl (1991) arguments treating geography as a "source of conflict", indicating that conflict occurs specifically because of geographic factors, and geography as a "facilitating condition for conflict". Vasquez (1995) distinguishes geographic factors by the nature of the factor in question, identifying three general theoretical perspectives. First, the territoriality perspective which is consistent with Diehl's "geography as a source of conflict"-suggests that geography is important primarily because states fight over territorial issues. The other two perspectives are associated more closely with Diehl's notion of a "facilitating condition for conflict"-suggest that geography is important primarily because it influences the ease with which states can reach each other militarily (the proximity perspective) or the frequency with which they interact with each other (the interaction perspective). Back in the $5^{\text {th }}$ century BC Greek historian mentions that the origins and execution of the war between the Greeks and the Persians are the perfect balance between geography and the decisions of men (Kalpan, 2012).

From the historical literature, it is clearly depicted that Geography plays a significant, fundamental role in shaping outcomes in human societies. Among other geographical elements, borders have significant implications. They are not only geographical figures, but also political creatures. It is natural that geographical features provide the foundation of countries; where a nation is physically located influences patterns of endogenous lifestyle and who are the neighbor countries for the nation is likely to set up exogenous international relations (Gottmann, 1973). Sun (2007) in his book (The Art of War) writes that "Not knowing the form of mountains and forests, defiles and gorges, marshes and swamps, one cannot move the arm. Not employing local guides, one cannot take advantage of the ground".

The earliest military strategists understood the role of geography and conflict. A soldier must become "familiar with the terrain: how mountains rise, how the 
valleys open out and plains spread out, as well as with the characteristics of rivers and swamps". Keegan (1993) in his History of Warfare features the role of geographic variables and distinguishes between "permanently operating" and "contingent" factors. Permanent factors include terrain and climate. These factors have long been the focus of military tacticians and military historians. Keegan's second concept, contingent geographic factors, relates to the constraints on logistics and intelligence. Geography is not just important on the battlefield, but at the operational level as well. As conflict having an impact on Geography, Geography, and in particular physical Geography, can have a major impact on conflict (Sun Tzu).

Many of the writers emphasize that geography is one of the basic factors that determine the events on the international scene. Concrete examples can be found in the present and smolder conflicts of Middle East, Arabian Peninsula, China, Pakistan, Bangladesh, Afghanistan and India (Kalpan, 2012).

\section{Geographical Factors}

Geography plays a significant, fundamental role in shaping outcomes in sector boundary of liberation war of Bangladesh 1971. Among other geographical attributes, boundary has significant implications, they are not only political figures, but also geographical creatures. It is natural that geographical features provide the foundation of countries; where a nation is physically located influences patterns of endogenous lifestyle and who are the neighbor countries for the nation is likely to set up exogenous international relations (Gottmann, 1951). During the liberation war all country divided by several zones, which known as sector. "Boundaries of sectors are the imaginary lines on the surface of the earth which separate the territory of one Sector from that of another". Boundaries serve both political and territorial functions. All boundary distinctions are artificial in the sense that they are man-made. A boundary that, physically separates the territory of one sector from that of another, does not only politically separate the two boundary states (Alam, 2015).

In the past only physical factor such as: streams, rivers, and mountain ranges were selected as a boundary but during the liberation war not only physical factor human factor also plays an important role in shaping the sector zone (Figure 2). Within the sector, the functional part is directed by sector commander. Each sector has a different sector commander. Boundary lines are neither uniform nor homogeneous; Aside from administrative convenience, it was felt that terrain features such as physiography and rivers exercised a natural separating function that was readily transferable to the political sphere (Gottmann, 1951).

Geography has a well-developed set of perspectives:

1) Geography's way of looking at the world through the lenses of place, space, and scale;

2) Geography's domains: Geography has two domains, one is Physical geography which deals with the natural features of the earth's surface, another is 


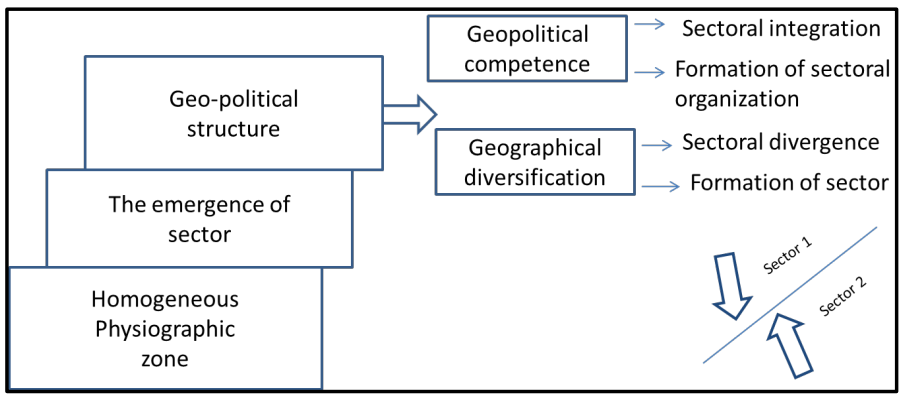

Figure 2. The process of formation of Sector boundary.

Human geography which dealing with how human activity affects or is influenced by the earth's surface;

3) Spatial representation using visual, verbal and cognitive approaches.

These three perspectives can be represented as dimensions of a matrix of geographic inquiry as shown below (Figure 3 ).

The matrix of geographic perspectives: Geography's ways of looking at the world - through its focus on place and scale (horizontal axis) - cuts across its two domains of synthesis: physical geography and human geography (vertical axis). Spatial representation, the third dimension of the matrix, underpins and sometimes drives research in other branches of geography.

A central tenet of geography is that "location matters" for understanding a wide variety of processes and phenomena. Indeed, geography's focus on location provides a cross-cutting way of looking at processes and phenomena that other disciplines tend to treat in isolation. Geographers focus on "real world" relationships and dependencies among the phenomena and processes that give character to any location or place. Geographers also seek to understand relationships among places: for example, flows of peoples, goods, and ideas that reinforce differentiation or enhance similarities. Geographers study the "vertical" integration of characteristics that define place as well as the "horizontal" connections between places. Geographers also focus on the importance of scale (in both space and time) in these relationships. The study of these relationships has enabled geographers to pay attention to complexities of places and processes that are frequently treated in the abstract by other disciplines.

Geographers approach spatial representation in a number of ways to study space and place at a variety of scales. Tangible representations of geographic space may be visual, verbal, cognitive, or some combination of these. Visual representation of geographic space through maps was a cornerstone of geographic. Geographers have drawn new attention to the power of both verbal and visual representations, exploring the premise that every representation has multiple, potentially hidden, and perhaps duplicitous, meanings (Strahler, 2013).

A serious geographic analysis of forming boundary can shed light on the spatial, territorial, and environmental dimensions. It raises questions about the nature and significance of particular political-territorial structures, the role of boundaries, the character of flows between places of influence and control, and 


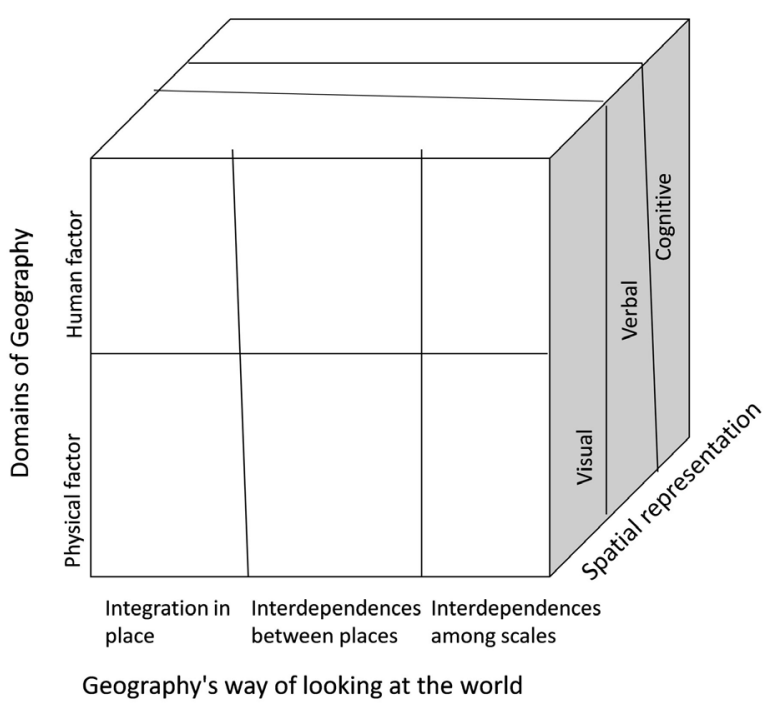

Figure 3. Matrix of geographic inquiry (modified after Strahler, 2013).

the role of the physical environment in shaping conflict and cooperation (Chang, 2010). In forming the sector boundary during the liberation war 1971 of Bangladesh the geographical factors play an important role which is presented in Table 2 and Map 1 below.

The 11 sectors of Bangladesh were formed based on several Geographical factors as follows:

1) Physiography of the region e.g., hilly, wetland, forest or plan land;

2) River boundary of the region;

3) Important Road intersection of the region;

4) Important Rail intersection of the region;

5) Administrative boundary of the region (Less important but adopted widely);

6) Accessibility with the Indian boarder.

How geography plays a fundamental role in shaping the outcomes in the sector boundary of the Liberation war of Bangladesh 1971 are briefly described in details below. The study constructs all sectors map in separately which shows with sub-sector. In this map, each sector map has undefined area which imitates this area is a part of this sector but this is not part of sub-sectors.

\section{Sector-1:}

Sector 1 is situated to the south-east side of Bangladesh. Geographically this region can be found between $20^{\circ} 35^{\prime}$ and $22^{\circ} 59^{\prime}$ North latitude and $91^{\circ} 27^{\prime}$ and $92^{\circ} 22^{\prime}$ East Longitude. This comprised of the districts of Chittagong and Chittagong Hill Tracts, and the entire eastern area of the Greater Noakhali district (Present day Feni district) on the banks of the river Muhuri (shown in Map 2 below). Area of this sector is almost $18,603 \mathrm{~km}^{2}$. The headquarters of the sector was at Harina.

Geographically this sector is diversified with various features. It consists of Hill-mountain, valley, lake, and river and ocean plain land. Main River is Sangu, Halda, Feni, Muhuri, Karnaufuly, Matamuhuri, Naf, Maheskhali, Bakkhali, 
Table 2. The eleven sectors shows in table and map.

\begin{tabular}{|c|c|c|c|}
\hline $\begin{array}{l}\text { Sector } \\
\text { No. }\end{array}$ & Area (Headquarter) & $\begin{array}{c}\text { Commanded } \\
\text { (duration of term) }\end{array}$ & Geographical Factor \\
\hline 1 & $\begin{array}{l}\text { Chittagong, Chittagong Hill } \\
\text { Tracts and Noakhali (Feni) } \\
\text { District up to Muhuri } \\
\text { River (Harina) }\end{array}$ & $\begin{array}{l}\text { Major Ziaur Rahman } \\
\text { (4 April-10 June 1971) } \\
\text { Major Rafiqul Islam } \\
\text { (11 June-16 December 1971) }\end{array}$ & $\begin{array}{l}\text { Chittagong Hill } \\
\text { Tracts and } \\
\text { Muhuri River }\end{array}$ \\
\hline 2 & $\begin{array}{l}\text { Eastern part of Greater } \\
\text { Faridpur, southern part of } \\
\text { Dhaka district including Dhaka } \\
\text { city (excluding northern part of } \\
\text { Akhaura-Ashuganj rail line), } \\
\text { Greater Noakhali district up } \\
\text { to the bank of Muhuri River } \\
\text { (Melaghar, } 20 \text { miles south } \\
\text { of Agartala, India) }\end{array}$ & $\begin{array}{l}\text { Major Khaled Mosharraf } \\
\text { (4 April-16 October 1971) } \\
\text { Major A. T. M. Haider } \\
\text { (17 October 1971-16 December } \\
1971 \text { ) }\end{array}$ & $\begin{array}{l}\text { Akhaura-Ashuganj } \\
\text { Rail line, Muhuri } \\
\text { River and } \\
\text { Administrative } \\
\text { Boundary }\end{array}$ \\
\hline 3 & $\begin{array}{l}\text { Habiganj, Kishoreganj, } \\
\text { Narsindi subdivision, Gazipur } \\
\text { subdivision and northern part } \\
\text { of Brahmanbaria, (Hejamara) }\end{array}$ & $\begin{array}{l}\text { Major K. M. Shafiullah } \\
\text { (4 April-30 September 1971) } \\
\text { Major A. N. M. } \\
\text { Nuruzzaman (1 October-16 } \\
\text { December 1971) }\end{array}$ & $\begin{array}{l}\text { Akhaura-Ashuganj } \\
\text { Rail line, Habiganj } \\
\text { tea garden and } \\
\text { administrative } \\
\text { boundary }\end{array}$ \\
\hline 4 & $\begin{array}{l}\text { Maulavibazar subdivision, } \\
\text { Southern half of Sylhet (initially } \\
\text { Karimganj, later Masimpur) }\end{array}$ & $\begin{array}{l}\text { Major Chittra Ranjan } \\
\text { Datta (17 July 1971-16 } \\
\text { December 1971) }\end{array}$ & $\begin{array}{l}\text { Maulavibazar tea } \\
\text { garden, Surma River } \\
\text { and administrative } \\
\text { unit }\end{array}$ \\
\hline 5 & $\begin{array}{l}\text { Northern half of Sylhet } \\
\text { and Sunamganj subdivision } \\
\text { (Banshtala) }\end{array}$ & $\begin{array}{l}\text { Major Mir Shawkat Ali } \\
\text { (August-16 December 1971) }\end{array}$ & $\begin{array}{l}\text { Surma River and } \\
\text { administrative unit }\end{array}$ \\
\hline 6 & $\begin{array}{l}\text { Present Rangpur division } \\
\text { excluding minor southern } \\
\text { trip (Burimari near Patgram) }\end{array}$ & $\begin{array}{l}\text { Wing Commander } \\
\text { M. K. Bashar } \\
\text { (June-16 December 1971) }\end{array}$ & $\begin{array}{l}\text { Barind track, Jamuna } \\
\text { River and } \\
\text { administrative unit }\end{array}$ \\
\hline 7 & $\begin{array}{l}\text { Present Rajshahi division } \\
\text { including part of } \\
\text { Thakurgaon-Dinajpur- } \\
\text { Gaibandha (Tarangapur } \\
\text { near Balurghat) }\end{array}$ & $\begin{array}{l}\text { Major Nazrul Huq } \\
\text { (11 April-28 September } \\
\text { 1971) Major Quazi } \\
\text { Nuruzzaman (1 October-16 } \\
\text { December 1971) }\end{array}$ & $\begin{array}{l}\text { Barind tract, Jamuna } \\
\text { River, Ganges River } \\
\text { and administrative } \\
\text { unit }\end{array}$ \\
\hline 8 & $\begin{array}{l}\text { Greater Kushtia and } \\
\text { Jessore district including } \\
\text { minor northern trip of } \\
\text { Khulna division (Kalyani) }\end{array}$ & $\begin{array}{l}\text { Major A. Osman Chawdhury } \\
\text { (4 April-15 August 1971) } \\
\text { Major M. A. Manzoor } \\
\text { (18 August-16 December 1971) }\end{array}$ & $\begin{array}{l}\text { Ganges river, } \\
\text { Khulna-Satkhira } \\
\text { road and } \\
\text { administrative unit }\end{array}$ \\
\hline 9 & $\begin{array}{l}\text { Greater Barisal, Patuakhali } \\
\text { and Khulna district excluding } \\
\text { northern tip of Satkhira } \\
\text { subdivision (Taki near } \\
\text { Bashirhat) }\end{array}$ & $\begin{array}{l}\text { Major M. A. Jalil } \\
\text { (11 April-16 December 1971) }\end{array}$ & $\begin{array}{l}\text { Khulna-Satkhira road } \\
\text { and Sundarban area }\end{array}$ \\
\hline 10 & $\begin{array}{l}\text { Bay of Bengal as well as } \\
\text { inland water bodies }\end{array}$ & $\begin{array}{l}\text { Bangladesh Navy under } \\
\text { Colonel M. O. G. Osmani }\end{array}$ & $\begin{array}{l}\text { Bay of Bengal } \\
\text { (Bangladesh area) }\end{array}$ \\
\hline 11 & $\begin{array}{l}\text { Greater Mymensingh and } \\
\text { Tangail district excluding } \\
\text { Kishoreganj subdivision and } \\
\text { including Raumari and Char } \\
\text { Rajibpur of Kurigram } \\
\text { subdivision (Mahendraganj) }\end{array}$ & $\begin{array}{l}\text { Major Ziaur Rahman } \\
\text { (10 June-12 August 1971) } \\
\text { Major Abu Taher (12 August- } \\
14 \text { November 1971) Flt. Lft. } \\
\text { M. Hamidullah Khan (15 } \\
\text { November-16 December 1971) }\end{array}$ & Administrative unit \\
\hline
\end{tabular}

Source: Compiled by author in 2018. 


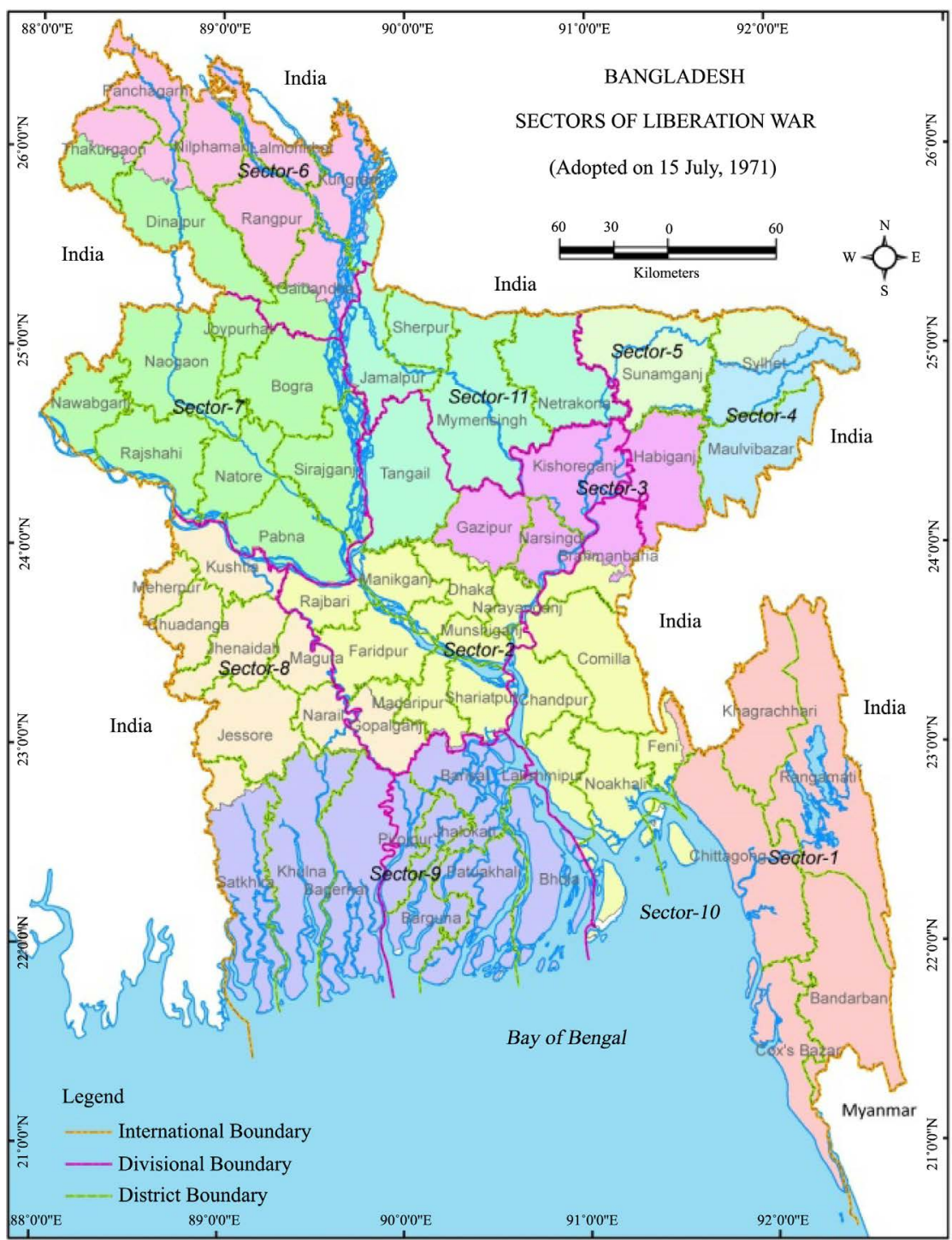

Map 1. Sectors of liberation war of Bangladesh. Compiled by author, 2020.

Rakiang, Kasalong, Maini, Chengi etc. This sector covered by mountain which is useful for guerrilla war. Main Mountain is Arakan, Sithakundu hill, Goll hill ad Batali hill etc.

During liberation war Chittagong ad Chittagong Hill Tracts is incredibly important because political, economic and military. Chittagong was second largest Port city of country. There was an Airport. There was Rail and Road communication with each region of country. West and East Pakistan distance was 1600 miles. There was no road for communication with two wings, only dependable way was water. Essential military instrument and food supplied from Karachi Port to Chittagong and Chalna port in ocean way. Sufficient road and rail way was present for freedom fighters communication other parts of the country. Rail way distributed Chattagram to Cumilla Akhaura. Chattagram, Feni, Lakhsam and Chandpur were connected with road and rail way. Geographically, this sector was important from military perspective. 


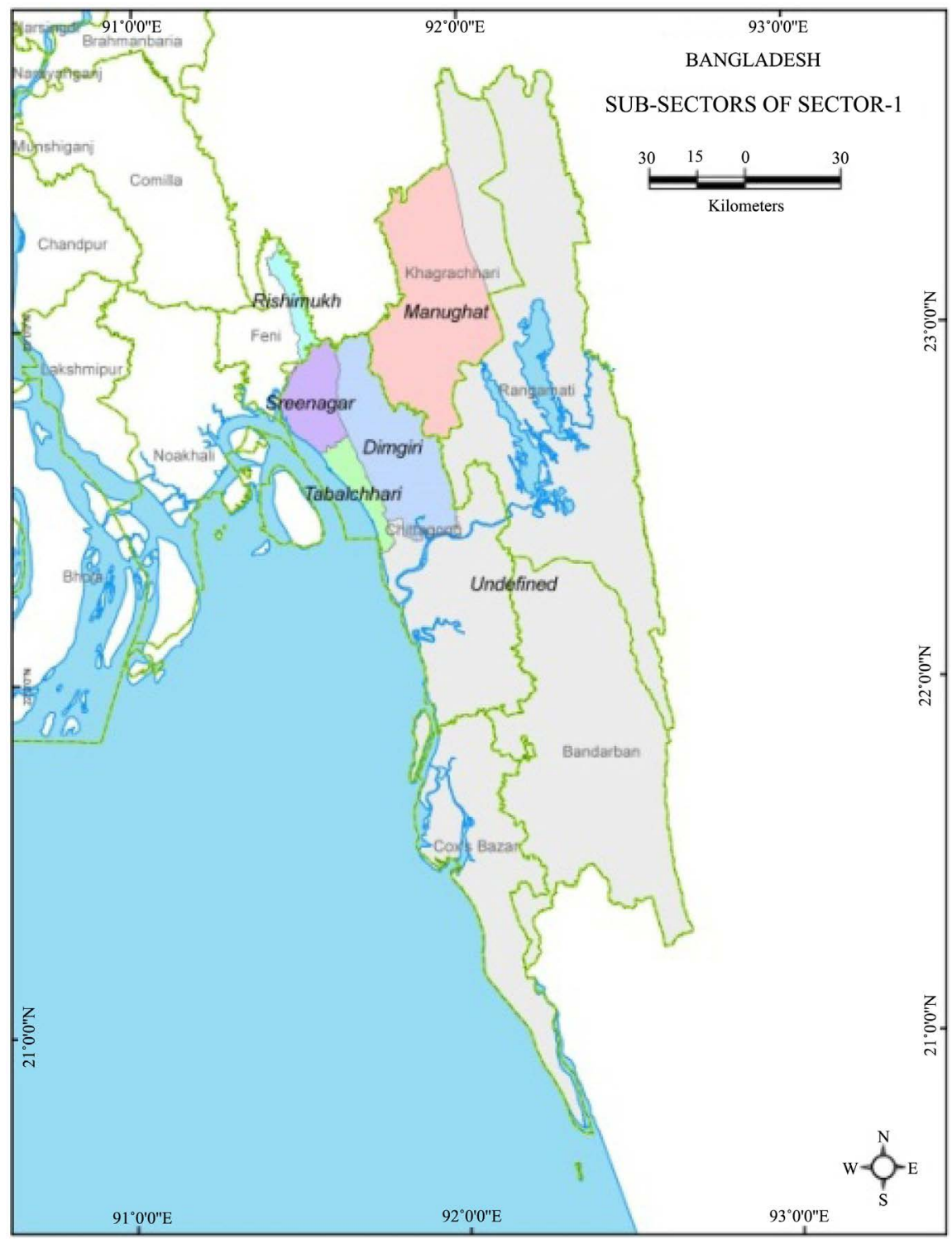

Map 2. Sector-1 with sub-sectors.

\section{Sector-2:}

Sector 2 is situated in the center of Bangladesh. Geographically this region can be found between $22^{\circ} 10^{\prime}$ and $24^{\circ} 00^{\prime}$ North latitude and $89^{\circ} 45^{\prime}$ and $91^{\circ} 45^{\prime}$ East longitude. This comprised of the part of Dhaka districts, Narayanganj district, Lakshmi purdistrict, Noakhali district, Feni district and Madaripur, Shariatpurdistrict, and Farid purdistrict (shown in Map 3 below). Area of this sector is 17,658 square kilometers. The headquarters of the sector was at Meghalaya of India. Relative location of this sector is South part of Bay of Bengal coastal area, South East side 1 no sector, East side Tripura state of India, Northern side 3 no sector, North-western corner Jamuna River and 7 no sector area, Western side 8 no sector area and South-western corner 9 no sector.

Main River are Buriganga, Dhaleshari, Ichamati, Bangsi, Turag, Dakatia, Katakhali, Rahmathkhali, Muhuri, Salda, Kritinasa, Kumar, Arial kha, Gorai, Old 


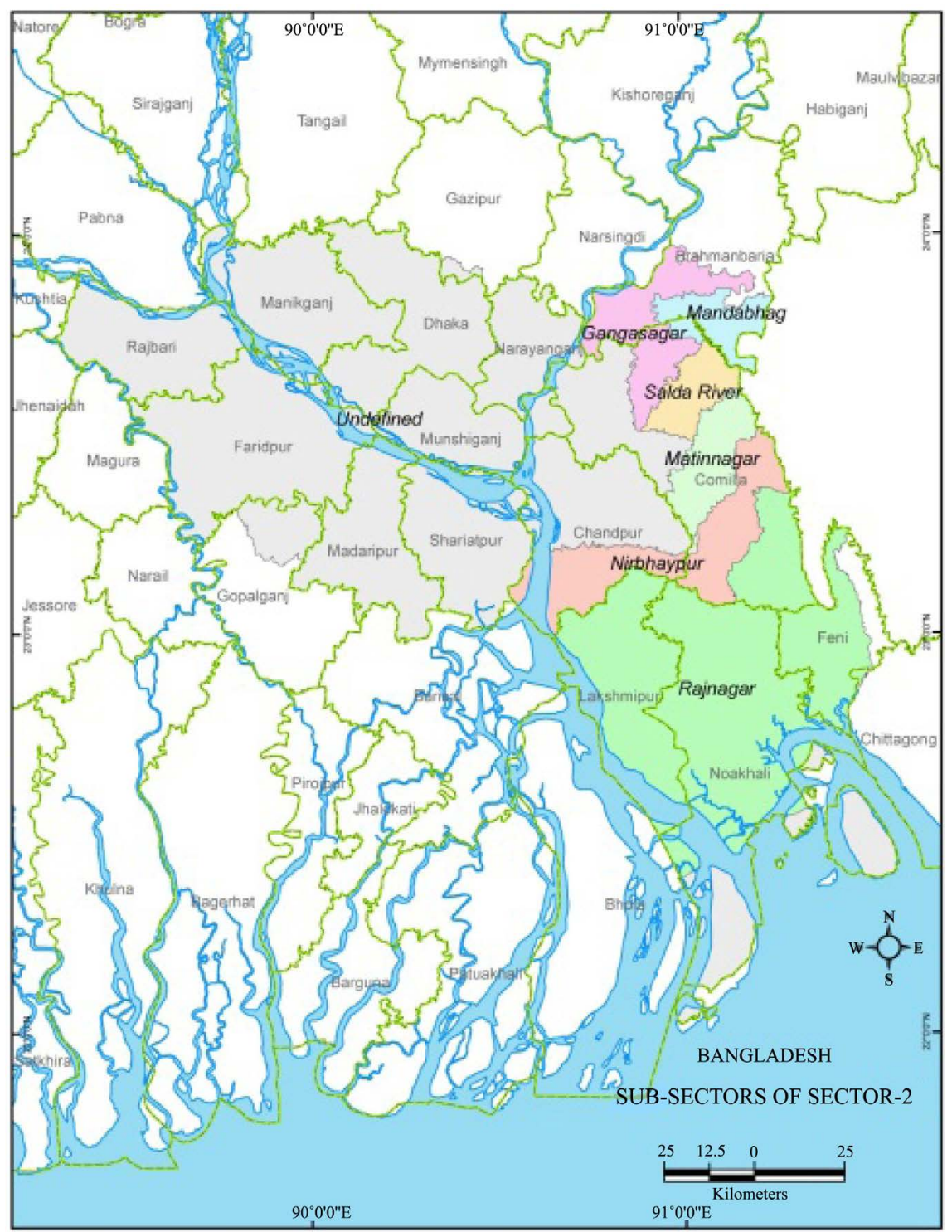

Map 3. Sector-2 with sub-sectors.

Brahmaputra etc. It is important to mention that three main river of Bangladesh cross this sector. Most of the Physiography of this sector was plain land. Dhaka is the Capital city of Bangladesh that's why significance of this sector is more than others sector.

1947 British citizen Sir M. Redcliff was selected for boundary identification of two wings of Pakistan but it is hard task. Redcliff identified geographical boundary of East Pakistanin 36 days hardwork. Two wings distance was 1600 miles. Mid-land is India. Bangladesh bounded with India almost $4000 \mathrm{~km}$ and South Eastern $193 \mathrm{~km}$ with Myanmar. During liberation war this Physiography of Bangladesh plays an important role. Pakistan army had no interest about South Eastern Hilly region. But important place of this sector was Mymensingh-Dhaka and Jamalpur-Tangail road. Mymensingh-Tangail road was main road. Armed importance's of Dhaka was very much because Dhaka was nodal point of poli- 
tics, radio, television, paper magazine, weather office, satellite connection, transmitter and telecommunication, central bank etc. For this reason this sector is more important. East Pakistan Riffles and Police Head Quarter was Dhaka which increase the military importance's that's why Pakistani army desired to broke these two armed force in 25 march night with "Operation Searchlight". Aware of these importance's of Dhaka "Muktibahini" divided guerrilla force in three groups for operation in Dhaka: Dhaka-North, Dhaka-South and Crack platoon. From 1969 Dhaka was central point for Bengali political movement. Specially students of Dhaka University. That's why Dhaka was first target of Pakistani army which proved of "Operation Searchlight".

For both parties Bhairab was important because Dhaka to Chattagram only communication was railway which crossed the Bhairab bridge. Disconnecting Dhaka to Chattagram communication and communication with eastern side of Bangladesh Bhairab was important point which area was $19.526 \mathrm{~km}^{2}$.

\section{Sector-3:}

Sector 3 comprised the area between Churamankathi (near Sreemangal) and Sylhet in the North and Singerbeel of Brahmanbaria in the South. Geographically this sector located between $23^{\circ} 90^{\prime}-24^{\circ} 60^{\prime}$ North latitude and $90^{\circ}-91^{\circ} 90^{\prime}$ East longitude. It consists of Kishoreganj district, Habiganj district, Gazipur district, Narsingdi district, North part of Brahmanbaria (shown in Map 4 below). The Headquarters of the sector was at Simna (Tripura).

Geographically this sector is diversified characteristics. It consists of Hill, valley, lake, river and plain land. Main Rivers are Old Brahmaputra, Meghna, Titas, Buri, Paharia, Hatidhoa, Kalni, Dhonu, Piyain, Barak, Shitalaksha, Arial Kha etc.

Sector-4:

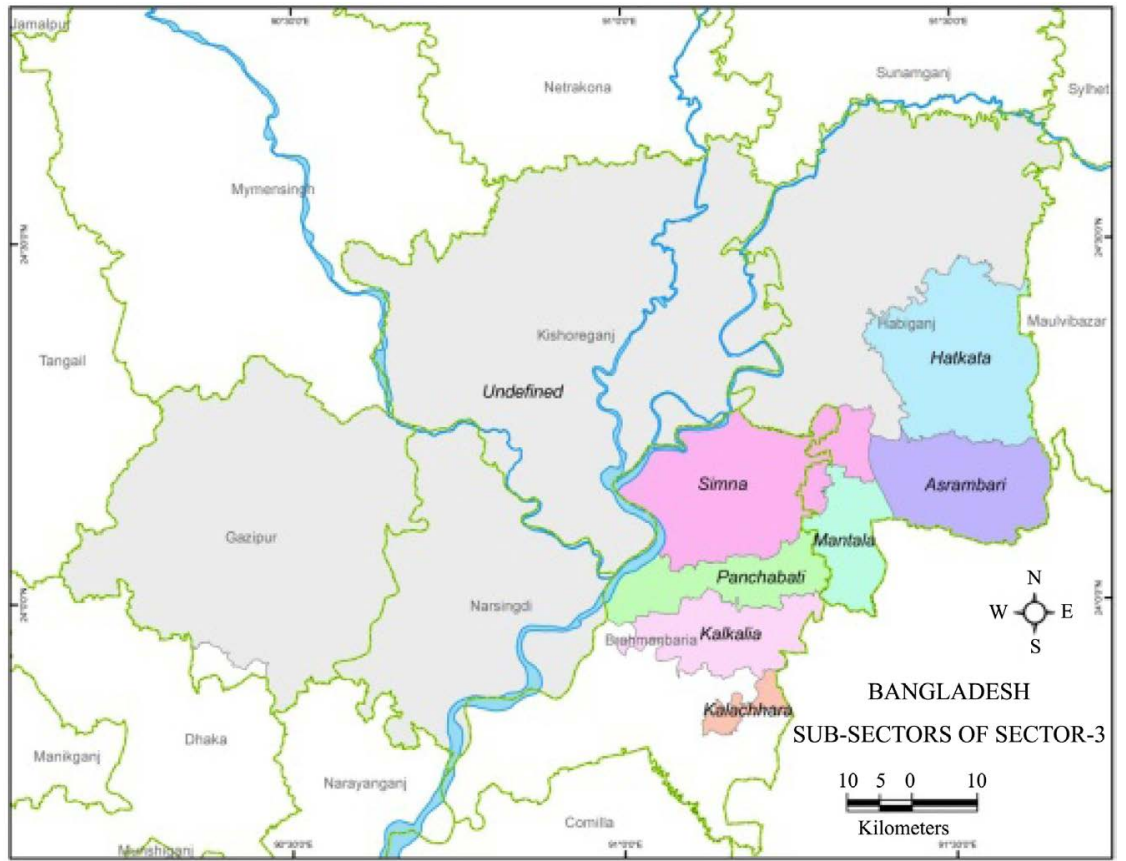

Map 4. Sector-3 with sub-sectors. 
Sector 4 is situated to the North-East side of Bangladesh. Geographically this region can be found between $23^{\circ} 90^{\prime}$ and $24^{\circ} 95^{\prime}$ North latitude and $91^{\circ} 30^{\prime}$ and $92^{\circ} 35^{\prime}$ East Longitude. It consists of Maulvibazar district, Kanaighat, Jakiganj, Bianibazar, Gopalganj, Fenchuganj, Balaganj, and BishanathThana of Sylhet (shown in Map 5 below). Area of this sector is almost $5900 \mathrm{~km}^{2}$. The Headquarters of the sector was initially at Karimganj and later at Masimpur.

Geographically this sector is diversified with various features. This sector consists of Hill, Tilla, Haor, Baor, Beel, Jeel, River, Plain land, Tea garden etc. This sector fulfills with mineral resources. Main Rivers are Surma, Kushiara.

\section{Sector-5:}

Sector 5 is situated to the North-east side of Bangladesh. Geographically this region can be found between $24^{\circ} 50^{\prime}$ to $25^{\circ} 10^{\prime}$ North latitude and $92^{\circ} 10^{\prime}$ to $92^{\circ} 30^{\prime}$ East longitude. This sector consists of Jaintapur Thana, Goainghat Thana, Companiganj Thana, Sunamganj Sadar, Chhatak Thana, Bishambarpur Thana, Doarbazar Thana, Jamalganj Thana etc. This Sector comprised the area from Durgapur to Danki (Tamabil) of Sylhet district and the entire area up to the eastern borders of the district. North side of Meghalaya and Assam of India, south side of Maulvibazar (4 no sector), western side of 11 no sector area and eastern side of Assam border area of India (shown in Map 6 below). The headquarters of the sector was at Banshtala.

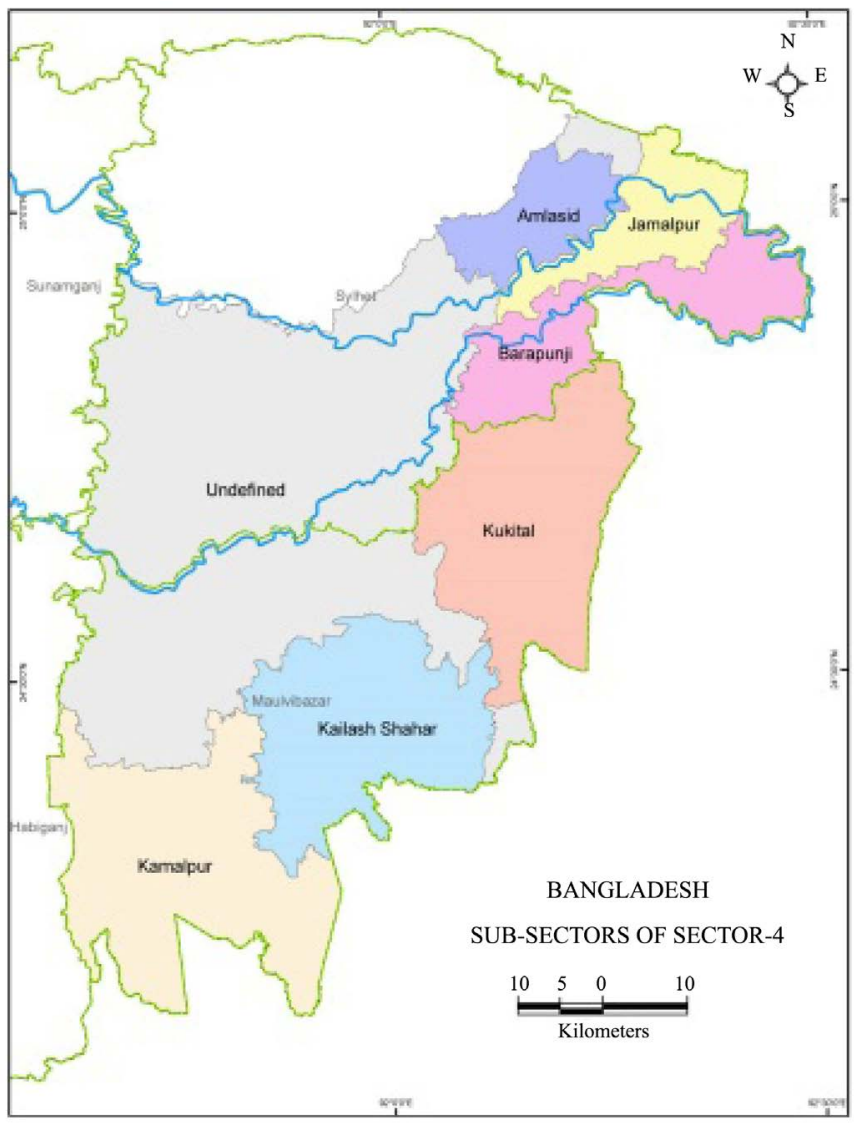

Map 5. Sector-4 with sub-sectors. 


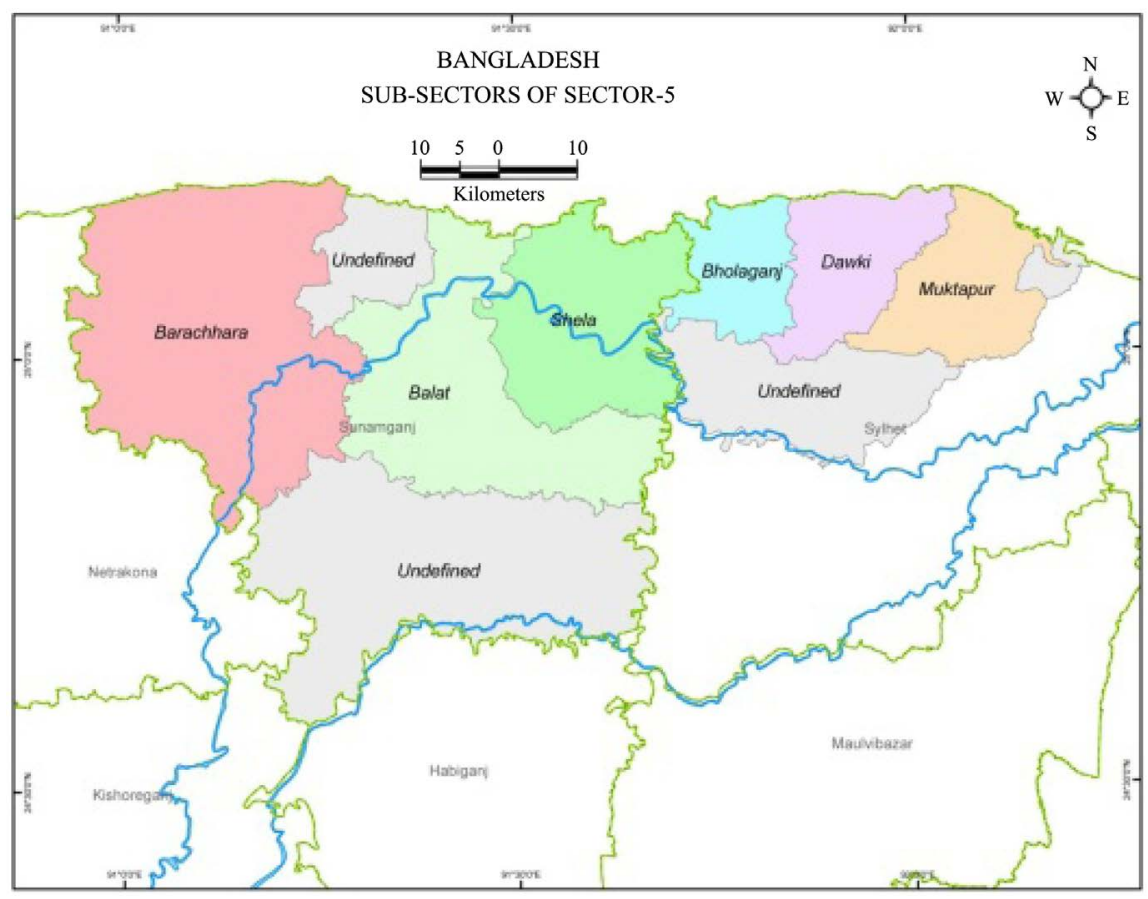

Map 6. Sector-5 with sub-sectors.

Forest area, Tea garden, undulating Hill, Tilla, River, Khal-beel, Haor etc. are the special characteristics of this sector. Main rivers of this area are Surma, Sarigaon, Piyain, Jadukata, Mahasingha etc.

\section{Sector-6:}

Sector 6 is situated to the North and North-west side of Bangladesh. Geographically this sector was located $25^{\circ} 20^{\prime}$ to $26^{\circ} 80^{\prime}$ North latitude and $88^{\circ} 10^{\prime}$ to $89^{\circ} 80^{\prime}$ East longitude. It comprised larger Rangpur district and Panchagar of Dinajpur district, Takurgaon sadar and Baliadangi Thana of Takurgaon district (shown in Map 7 below). Total area of this sector was 9555.56 sq. kilometer. The Headquarters of the sector was at Burimari near Patgram.

Geographically this sector is diversified characteristics. Main strategic important place was Hilli-Goraghat-Gaibandha area of this sector. Three Thana of this sector; Tentulia, Fulbari, Patgram never Pakistani army enter for various strategic plan.

\section{Sector-7:}

Sector 7 is situated to the North-west side of Bangladesh. Geographically this sector located $24^{\circ}$ to $25^{\circ} 20^{\prime}$ North latitude and $88^{\circ} 10^{\prime}$ to $89^{\circ} 80^{\prime}$ East longitude. This sector consists of greater Rajshahi, Pabna and Bogra districts and North side Saghata of Gaibandha district, South side of Gobindaganj Thana and South side of Goraghat, Nawabganj, Birampur, Fulbari, Dinajpur Sadar, Birol, Bochaganj Thana road. Northern side of this sector was 6 no sector, Southern side Padma river and 8 no sector boundary, Eastern side Jamuna river and 11 no sector boundary and western side West Bengal of India (shown in Map 8 below). Area of this sector is almost $19,197 \mathrm{~km}^{2}$. The Headquarters of the sector was at Taranngapur in West Bengal. 


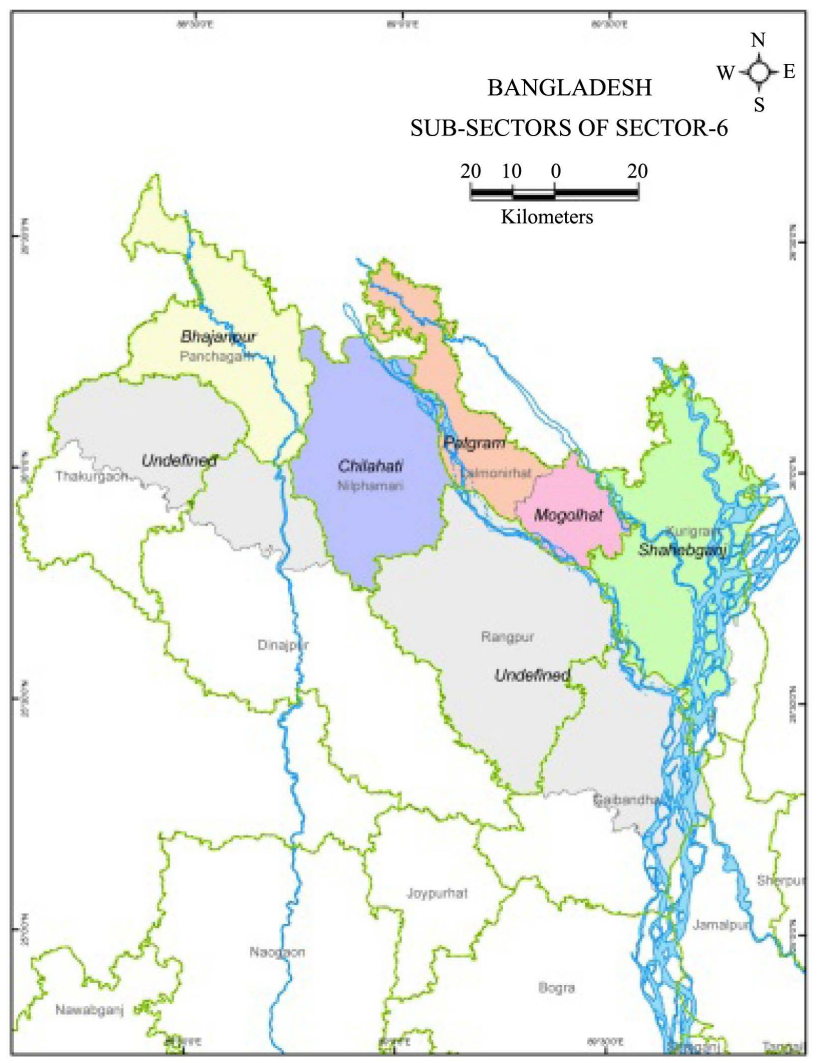

Map 7. Sector-6 with sub-sectors.

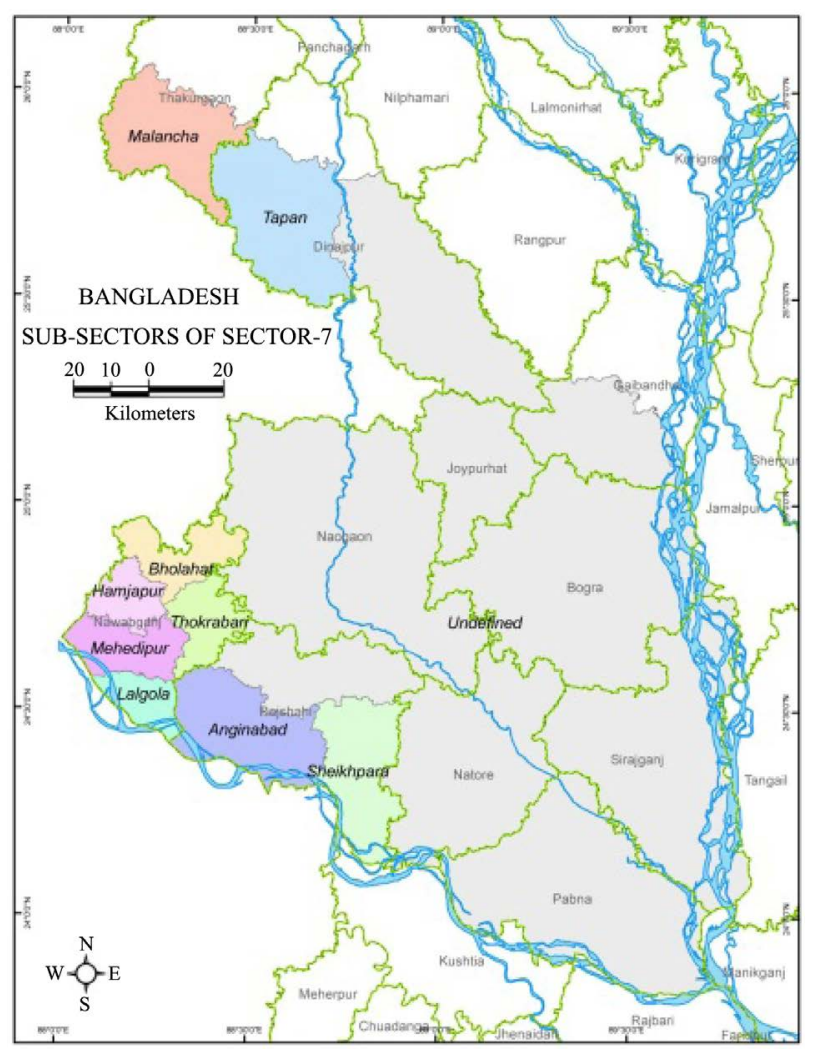

Map 8. Sector-7 with sub-sectors. 
Main Rivers of this sector as; Mahananda, Pagla, Shib, Barnai, Atria, Purnavaba, Tulsi Ganga, Irabati, Nagor, Narod, Chiri, Ichamati, Boral, Hurasagar, Kartoa, Bangali, Godaietc. Chalanbeel is the prominent beel of this region.

\section{Sector-8:}

Sector 8 is situated to the South-west side of Bangladesh. Geographically this region can be found between $22^{\circ} 65^{\prime}$ and $24^{\circ} 5^{\prime}$ North latitude and $88^{\circ} 90^{\prime}$ and $90^{\circ} 5^{\prime}$ East Longitude. This sector comprised with the Greater Kushtia and Jessore district and up to Daulatpur-Sathkhira road of Khulna district (shown in Map 9 below). The Headquarters of the sector was at Benapole.

Geographically this sector is diversified characteristics. It consists of lake, river and flood plain lands. Main Rivers are Padma, Madumathi, Ichamathi, Bhairab, Mukteshari, Garai, Kumar, Nabganga, Begbathi, Chitra, Kapotakko, Katki, Kaliganga, Kajla, Mathavanga, Arial Kha.

\section{Sector-9:}

Sector 9 is situated to the South and South-west side of Bangladesh: Geographically this sector located $21^{\circ} 65^{\prime}$ to $22^{\circ} 65^{\prime}$ North latitude and $89^{\circ}$ to $91^{\circ}$ East longitude. This Sector comprised the districts of Barisal and Patuakhali, and parts of the district of Khulna and Satkhira. It consists of the Daulatpur-Sathkhira road to South side of Greater Khulna, Barishaland Patuakhalidistrict. North side of this sector is 8 no sector, South side Bay of Bengal, Eastern side Meghna river and 2 no sector and western side west Bengal of India (shown in Map 10 below).

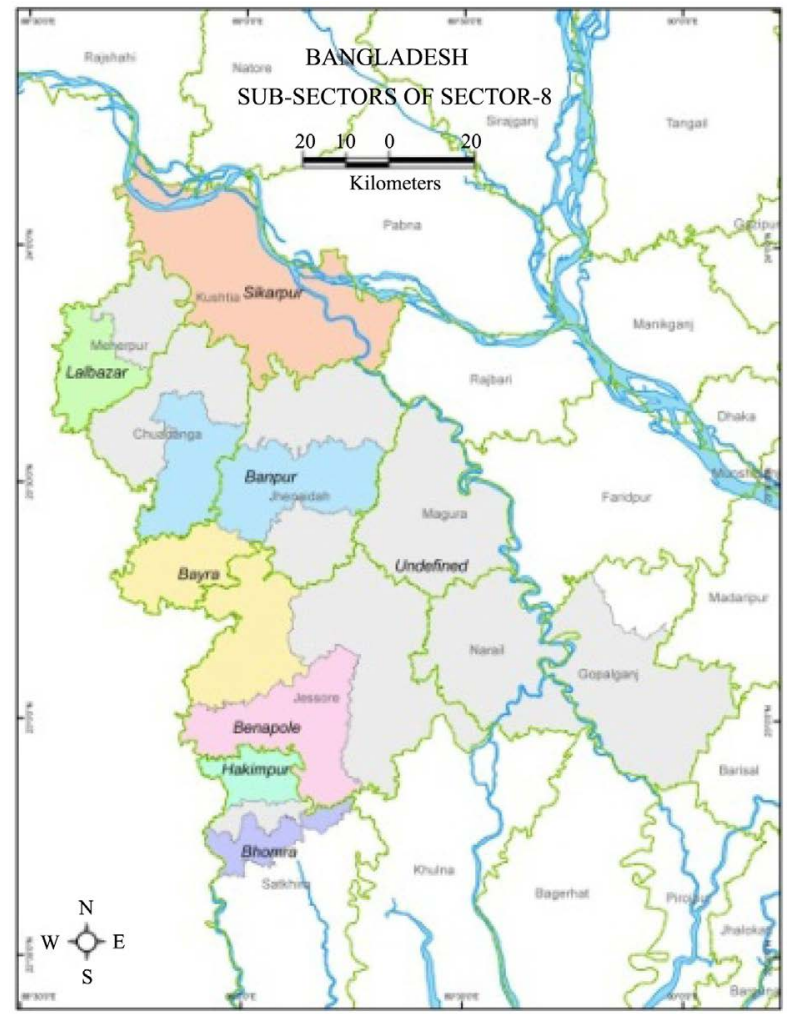

Map 9. Sector-8 with sub-sectors. 


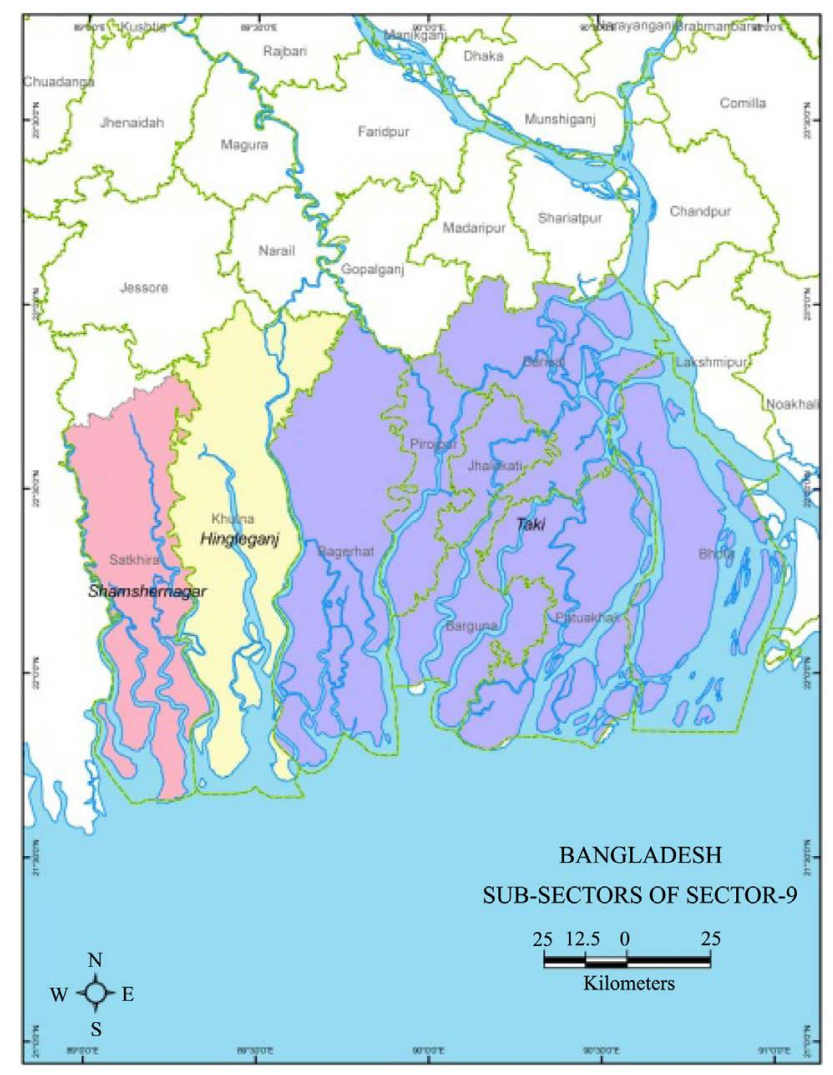

Map 10. Sector-7 with sub-sectors.

\section{Sector-10:}

This sector was constituted with the naval commandos. Eight Bengali officers of Pakistan Navy trained in France were the pioneers in forming this force. These eight officers were given special training under the auspices of the Indian Navy. The force was later commanded by Indian commander MN Sumanta. Naval Commandos conducted major operations in river and Seaports at Chattagram, Mongla, Narayanganj and Chandpur. This Naval Commando was placed directly under Commander in Chief of Bangladesh Liberation Armed Force.

\section{Sector-11:}

Sector 11 is situated to the Northern side of Bangladesh. Geographically this region can be found between $24^{\circ} 10^{\prime}$ to $25^{\circ} 20^{\prime}$ North latitude and $89^{\circ} 20^{\prime}$ to $91^{\circ} 45^{\prime}$ East longitude. This comprised of Sherpur Upazila, Jamalpur, Netrokona, Mymensingh of Greater Mymensingh district, Tangail district, part of Kurigram, and Western side of Jamuna River with Roumary of Kurigram Upazila, Char Rajibpur Upazila. Northern side of this sector is Assam, Meghalaya of India, Southern side Manikganj of 2 no sector, Gazipur of 3 no sector, Kishoreganj, Habiganj, Western side Brahmaputra and Jamuna and Eastern side 4 no and 5 no sector. The Headquarters of the sector was at Mahendraganj (shown in Map 11 below).

Geographically this sector is diversified features. Pleistocene Hill such as Garo hill, Madupur tilla, Sakhipur tilla, Gatail tilla etc. situated here. Main Rivers are 


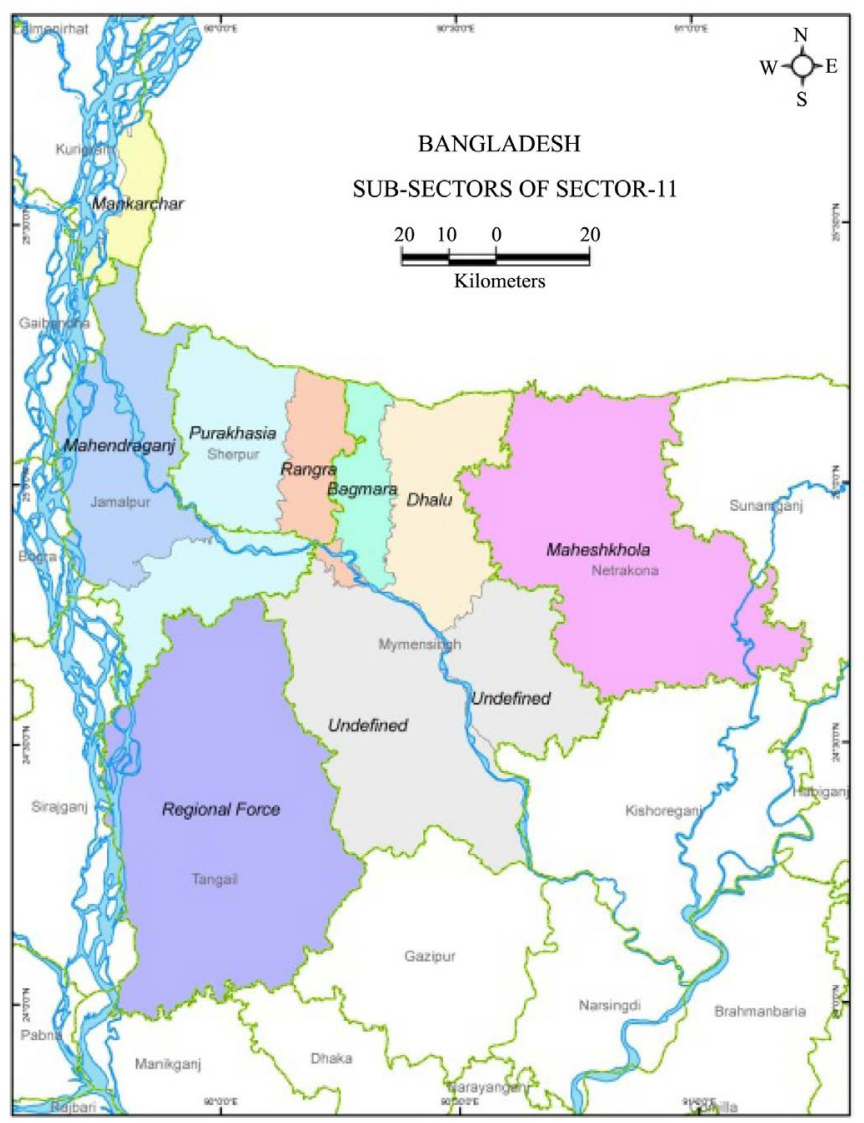

Map 11. Sector-8 with sub-sectors.

Old Brahmaputra, Jamuna, Dhaleshari, Someshari, Bangshi, Turag, Dhanu, Dhala, Banar, Chatal, Voghai etc. Important Beels and Haors are Kajipur Beel, Aurabaura, Dhala, Hatia, Bheramara etc.

The Geographical diversification explains in above discussion which contributed to shaping the form of Sector boundary of 1971 liberation war of Bangladesh. Each sector boundary controlled by Geographical factors might be physical or human factors such as; Muhuri river, Chattogram Hill Tracts, Akhaura-Ashuganj Rail line, Sylhet hilly area, Haor region, Surma and Kushiara river, Beel, Jamuna river, Tista river, Padma river, Khulna-Satkhira high way, Sundarban region, Bay of Bengal and Administrative boundary Which shaping the formed of sector boundary.

\section{Conclusion}

The formation of the sectors for strategic plan in July was thus played a key role to demolish Pakistani army. The formation of the sectors was epochal and strategic plan for winning the glorious history. Geography plays a significant role in shaping outcomes in sector boundary of liberation war of Bangladesh 1971. The sectors were formed based on geographical attributes of whole country such as; physical and cultural features of country. This research identifies key geographical factors which play a crucial to forming the sectors on the liberation war of 
Bangladesh. It was about the winning history of Bangladesh after July 1971. The canvas of Bangladesh's Liberation war is very wide. Armed resistance is an important part of that canvas. The military crackdown on $25^{\text {th }}$ of March 1971 puzzled the Bengali people. There was no organized strategy to battle against the Pakistani military force. Several scattered and isolated groups of armies and other force officials revolved but these were not sufficient to fight in front war. Initially, the strategy was to defense and survive. It was about the winning history of Bengali after July 1971.

\section{Conflicts of Interest}

The author declares no conflicts of interest regarding the publication of this paper.

\section{References}

Alam, A. (2015). Geographical Factors in Cultural Aspects of Early Bengal (5th to 13th Centuries CE). Journal of Bengal Art, 20, 309-322.

https://www.academia.edu/25606654/Geographical_Factors_in_Cultural_Aspects_of_E arly_Bengal_5th_to_13th_Centuries_CE

Banglapedia (2012). Banglapedia Upazila Profiles (10 Volume). Dhaka: Asiatic Society of Bangladesh.

Chang, B. (2010). The Power of Geographical Boundaries: Cultural, Political, and Economic Border Effects in a Unitary Nation. Graduate Theses of Iowa State University USA. https://lib.dr.iastate.edu/etd/11344

Diehl, F. P. (1991). Geography and War: A Review and Assessment of the Empirical Literature. International Interactions, 17, 11-27. https://doi.org/10.1080/03050629108434768

Gottman, J. (1951). Geography and International Relations. World Politics, 3, 153-173. https://doi.org/10.2307/2008950

Gottmann, J. (1973). The Significance of Territory. Charlottesville: The University Press of Virginia.

http://www2.fct.unesp.br/docentes/geo/bernardo/BIBLIOGRAFIA\%20DISCIPLINAS\% 20POS-GRADUACAO/JEAN\%20GOTTMANN/Gottman,\%20Jean\%20The\%20Signifi cance $\% 20$ of\% 20territory.pdf

Government of Bangladesh (2006). Bangladesher Sector bhittik Etihas (Vol. 11). Dhaka: Ministry of Liberation War Affairs.

Kalpan, R. D. (2012). The Revenge of Geography: What the Map Tells Us about Coming Conflicts and the Battle against Fate. New York: Random House.

Keegan, J. (1993). A History of Warfare. New York: Vintage.

Mamun, M. (2012). Muktijuddo Kosh. Dhaka: SamayProkasoni.

Maniruzzaman, T. (1980). The Bangladesh Revolution and Its Aftermath. Dhaka: Bangladesh Books International Limited.

Mukul, M. R. A. (2004). Ami Bijoy Dekhechi. Dhaka: Sagar Publishers.

Provisional Government of Bangladesh (1971). Proclamation of the Independence of Bangladesh.

http://www.docstrangelove.com/uploads/1971/sbbk/documents/Proclamation\%201971 =M_Dalil_Vol_03_MMR.pdf 
Rahman, H. H. (1982). Bangladesher Shadinatha Judder Dalilpatro (10th Volume). Dhaka: Ministry of Information.

Strahler, A. (2013). Introducing Physical Geography (6th ed.). Hoboken, NJ: Wiley.

Sun, Z. (2007). The Art of War: Sunzi's Military Methods (Translated by Victor H. Mair). New York: Columbia University Press.

Vasquez, J. A. (1995). Why Do Neighbors Fight? Proximity, Interaction, or Territoriality. Journal of Peace Research, 32, 277-293. https://doi.org/10.1177/0022343395032003003 